\title{
Energy Impact of Cathode Drying and Solvent Recovery during Lithium-ion Battery Manufacturing
}

\author{
Shabbir Ahmed (Corresponding Author) \\ Chemical Sciences and Engineering Division, Argonne National Laboratory, Bldg. 200, \\ 9700 S. Cass Avenue, Argonne IL 60439 USA \\ ahmeds@anl.gov, Tel: (630) 252-4553, Fax: (630) 972-4553
}

\author{
Paul A. Nelson \\ Chemical Sciences and Engineering Division, Argonne National Laboratory, Bldg. 200, \\ 9700 S. Cass Avenue, Argonne IL 60439 USA \\ nelsonp@anl.gov \\ Kevin G. Gallagher \\ Chemical Sciences and Engineering Division, Argonne National Laboratory, Bldg. 200, \\ 9700 S. Cass Avenue, Argonne IL 60439 USA \\ kevin.gallagher@anl.gov \\ Dennis W. Dees \\ Chemical Sciences and Engineering Division, Argonne National Laboratory, Bldg. 200, \\ 9700 S. Cass Avenue, Argonne IL 60439 USA \\ dees@anl.gov
}

(C) 2016. This manuscript version is made available under the Elsevier user license http://www.elsevier.com/open-access/userlicense/1.0/ 


\begin{abstract}
Successful deployment of electric vehicles requires maturity of the manufacturing process to reduce the cost of the lithium ion battery (LIB) pack. Drying the coated cathode layer and subsequent recovery of the solvent for recycle is a vital step in the lithium ion battery manufacturing plant and offers significant potential for cost reduction. A spreadsheet model of the drying and recovery of the solvent, is used to study the energy demand of this step and its contribution towards the cost of the battery pack. The base case scenario indicates that the drying and recovery process imposes an energy demand of $10 \mathrm{kWh}$ per kg of the solvent n-methyl pyrrolidone (NMP), and is almost 45 times the heat needed to vaporize the NMP. For a plant producing $100 \mathrm{~K}$ battery packs per year for $10 \mathrm{kWh}$ plug-in hybrid vehicles (PHEV), the energy demand is $\sim 5900 \mathrm{~kW}$ and the process contributes $\$ 107$ or $3.4 \%$ to the cost of the battery pack. The cost of drying and recovery is equivalent to \$1.12 per kg of NMP recovered, saving $\$ 2.08$ per $\mathrm{kg}$ in replacement purchase.
\end{abstract}

\title{
Keywords
}

Lithium-ion battery; manufacturing; cathode solvent; energy need; n-methyl pyrrolidone 


\section{Table of Contents}

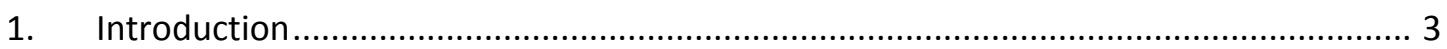

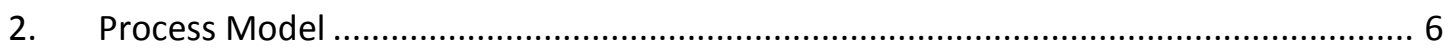

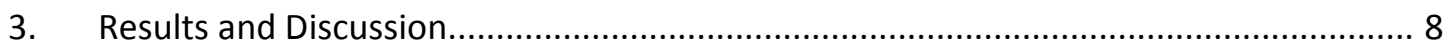

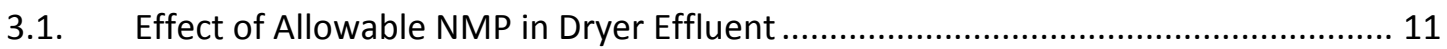

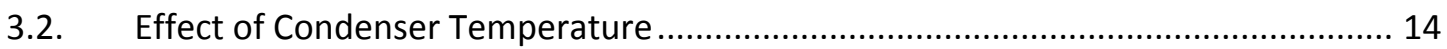

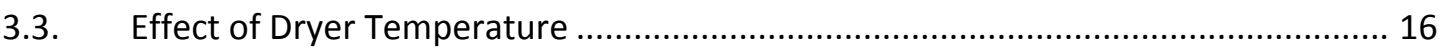

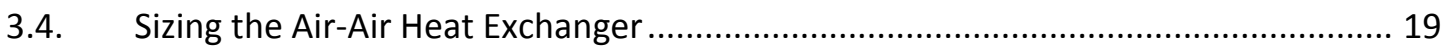

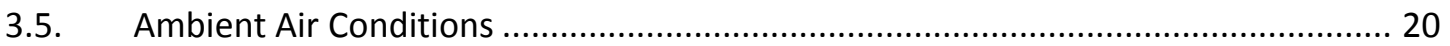

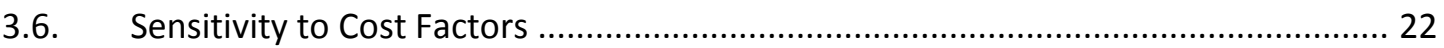

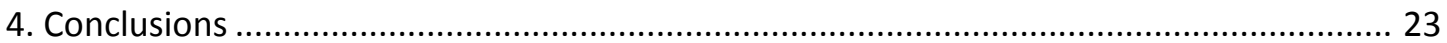

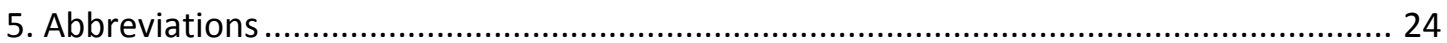

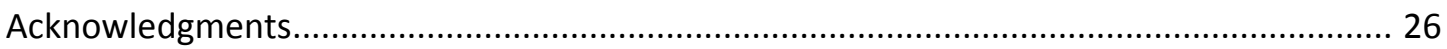

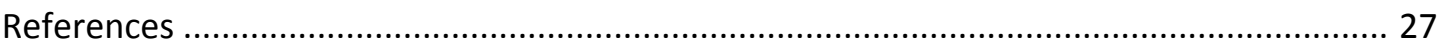




\section{Introduction}

The increasing deployment of electric vehicles is accompanied by a greater impetus towards reducing the cost of lithium ion batteries (LIB). While new chemistries can offer breakthroughs by introducing cheaper materials with higher capacity, safety, and durability, their manufacturing process (Nelson, Gallagher, Bloom, \& Dees, Modeling the Performance and Cost of Lithium-Ion Batteries for Electric Vehicles, 2011) (Lawson) has to limit the cost of the final product (the pack) through process simplifications and optimization (Westphal, Bockholt, Gunther, Haselrieder, \& Kwade, 2015) (Kim \& Rhee, 2011). Industry continues to study each step in the battery manufacturing process and is seeking alternatives that can lead to faster production and lower cost. The work reported in this paper explores the cathode drying process in the manufacturing plant its energy demand and contribution to the cost of the battery pack.

The cathode is composed of lithium metal oxide particles such as for example $\mathrm{LiMn}_{2} \mathrm{O}_{4}, \mathrm{Li}_{a} \mathrm{Ni}_{x} \mathrm{Mn}_{y} \mathrm{Co}_{z} \mathrm{O}_{2}$, etc. , carbon black conductive additive such as acetylene black, graphite, etc., and polymeric binder such as polyvinylidene difluoride (PVDF) typically in an approximate mass ratio of 94:3:3 in the dried state. Different kinds of solids are first dry mixed, and then mixed with a solution of the binder dissolved in the solvent, $\mathrm{n}$ methyl pyrrolidone (NMP) (Agency), which is water soluble to form a slurry. The mixing condition has a strong impact on the slurry and ultimately the battery performance (Tagawa \& Brodd, 2009). The slurry is coated on to both sides of the cathode current collector (i.e., aluminum foil) (Li, Daniel, \& Wood, 2011) using techniques such as the slot die coating heads. The alternate sides may be coated on a completely separate pass 
through the same coating line, at a second coating station installed after the first drying oven or nearly simultaneously before entering the drying oven. The dried coating thicknesses are typically less than 80 microns. The electrode coats are interrupted at intervals where the currents collectors will be slit (farther downstream) to match the length or width of the electrodes. The electrode-coated current collector is then passed through the dryer to evaporate the liquid content (NMP in the cathode, water in the anode). The dryer closely follows the coating station and stretches for several meters to ensure a drying rate that maintains the desired particle size, porosity (the porosity may be further reduced during calendaring downstream) and distribution. The coated sheet is slit at the intervals to produce the electrode layers which can be stacked (or rolled in the case of cylindrical cells) together with the separator layer. The cells are vacuumassisted filled with electrolyte before sealing. The formation cycling process consists of charging and discharging the cells according to a manufacturer optimized protocol to facilitate the activation of the solid electrolyte interface, a critical layer needed for the cycle life of the cathode. The cells are then stored for a period at a certain state of charge to check for shelf life as part of the quality control process. The cells that pass the requirements are then ready for shipping.

Tagawa and Brodd (Tagawa \& Brodd, 2009) provide more details about the electrode processing. The performance of the cell is strongly influenced by the electrode preparation which includes the choice of additives, mixing ratios, mixing and dispersing techniques to produce the desired electrode structure (Wenzel, Nirschl, \& Notzel, 2015), drying method and rate (Westphal, Bockholt, Gunther, Haselrieder, \& Kwade, 2015) 
(Kim \& Rhee, 2011), and compacting to improve electronic conductivity (Tran, Greco, Taubert, Wohlfahrt-Mehrens, Haselrieder, \& Kwade, 2012). Inconsistencies in the manufacturing of the electrode layers have a significant impact on the cell and module performance, resulting in lower or unavailable capacity, and capacity fade. Electrode thickness and porosity are important parameters for useful capacity (Kenney, Darcovich, MacNeil, \& Davidson, 2012) and internal resistance (Vayrynen \& Salminen, 2012); these characteristics require careful control during the slurry preparation (Bockholt, Haselrieder, \& Kwade, 2013), coating, drying (Westphal, Bockholt, Gunther, Haselrieder, \& Kwade, 2015) (Kim \& Hyun, 2001) (Gutoff), and calendering (Haselrieder, Ivanov, Christen, Bockholt, \& Kwade, 2013) (Wolter, Leiva, Fritsch, \& Borner, 2013).

The NMP evaporated in the dryer is subsequently recovered and recycled, resulting in significant cost savings from the combination of avoided replacement cost and waste/emissions reduction. It is recognized that the cost savings and environmental benefits might be significantly greater if the use of solvents for the coatings could be avoided altogether by applying the coatings in a dry state (Abe, Kondo, Naito, Wakimoto, \& Yamaguchi, 2013). However, that is not the subject of this study.

Argonne has a spreadsheet tool, BatPaC (Nelson, Gallagher, \& Bloom, BatPaC (Battery Performance and Cost) Software, 2012; Nelson, Gallagher, Bloom, \& Dees, Modeling the Performance and Cost of Lithium-Ion Batteries for Electric Vehicles, 2011; Gallagher \& Nelson, 2014), that is used by researchers and organizations to design and estimate the cost of automotive LIB packs. It calculates the pack cost based on the 
contributions from a large number of processing steps. Petri et. al. (Petri, Giebel, Zhang, Schunemann, \& Hermann, 2015) reviews and compares three models, including BatPaC; other lithium ion battery models include a cost model developed by TIAX (Barnett, et al., 2009) and a lifetime model by the National Energy Renewable Laboratory (NREL) (Smith, Neubauer, Wood, Jun, \& Pesaran, 2013).

The objective of this work is to study the energy demand and distribution for the drying of the cathode and the process for the recovery of the solvent (NMP), and to estimate the cost of this process. The spreadsheet model reported in this work is designed to review and update the estimates used in the $\mathrm{BatPaC}$ model, by looking more closely at mass and energy balances of the many unit operations in the process and follow through with more detailed estimates of the cost contributors. Results from this reported model will be used to update BatPaC input parameters, as needed.

\section{Process Model}

The NMP recovery process studied here is for a battery manufacturing plant producing 100,000 packs per year of $60 \mathrm{~kW}, 10 \mathrm{kWh}$ plug-in hybrid vehicle (PHEV) batteries, where each pack costs approximately $\$ 3100$ (\$310 per kWh). Over 4.1 million kg per year of NMP is used for depositing the cathode layers.

Consider the process as shown in Figure 1, where the NMP in the cathode is evaporated in the dryer by exposure to flowing hot air. The air leaves the dryer at a specified temperature and the maximum allowable NMP concentration $\left(140^{\circ} \mathrm{C}\right.$ and 1150 
parts per million by volume (ppm) for the base case scenario). The NMP-laden hot air is first passed through an air-to-air heat exchanger - transferring part of the sensible heat to the incoming air, and then it is cooled in a chilled water condenser. The NMP, water, and higher hydrocarbons (degradation byproducts from the NMP processing) in the liquid condensate are separated in a distillation column. The cooled air from the condenser, containing a few ppm of NMP, is split into the recycle and purge streams. The purge stream is passed through a zeolite wheel where most of the NMP is adsorbed, followed by water scrubbing before it is sent out as exhaust. 


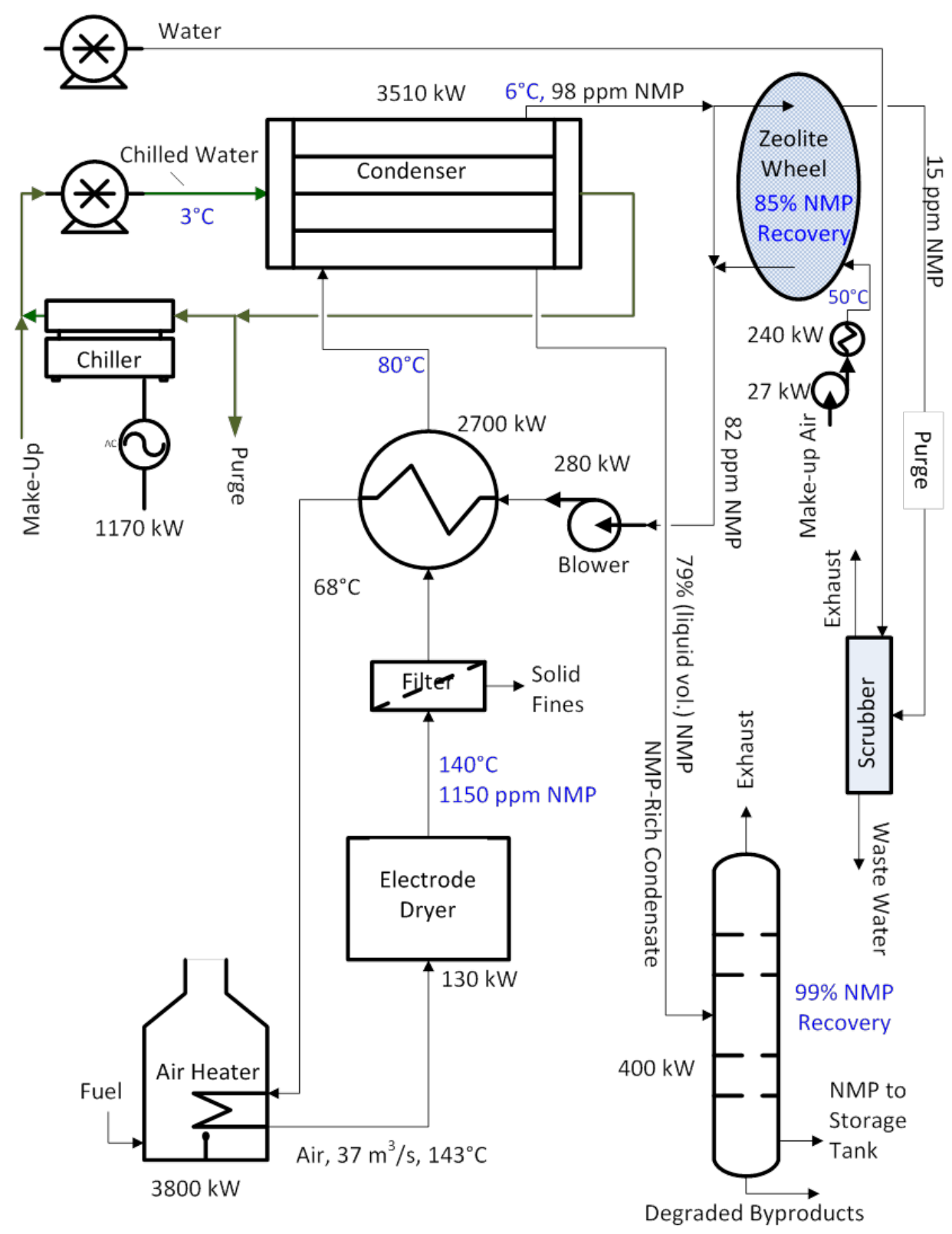

Figure 1. Process schematic for the drying and recovery of the cathode solvent NMP in a battery manufacturing plant (Base Case: $4.1 \cdot 10^{6} \mathrm{~kg}$ NMP evaporated per year)

Ambient air is drawn in as make-up and is heated to a temperature above $50^{\circ} \mathrm{C}$ and passed through the zeolite wheel, thereby desorbing the trapped NMP, to regenerate the zeolite. The NMP containing make-up air is combined with the recycle stream from 
the condenser and passed through the air-to-air heat exchanger, preheating it on its way to the air heater. The recycled air is indirectly heated in the air heater and then fed into the cathode dryer. Indirect heating is advantageous in that it does not add any moisture (combustion product) to the dryer air. In an alternative system design, the recycled air can be blended with hot combustion air from a burner to eliminate the heat transfer surfaces in the indirect heater, but the combustion air will introduce moisture into the dryer air, increasing the loads of the condenser and the distillation column.

A base case set of process conditions was selected to estimate the energy and cost of operation of the drying and recovery process. Table 1 lists the input conditions used in the process model.

Table 1. Input parameters for the Base Case set of design and operating conditions

\section{Results and Discussion}

The core necessity of this process is the removal of NMP from the cathode and to recover and recycle the same. The heat needed to vaporize the NMP from the cathode material is a moderate $130 \mathrm{~kW}$, for the base case scenario. But the NMP has to be vaporized in a controlled manner to avoid damaging the morphology of the cathode coating, and the NMP vapor concentration in the gas phase has to be maintained far below the lower flammability limit, which is approximately $1.1 \%$ at $140^{\circ} \mathrm{C}$. This latter 
constraint imposes the requirement that a large amount of heated air be used for the drying process. Heating the large volume of air raises the heat load considerably.

For the process studied here, the heat load for the air heater, $3752 \mathrm{~kW}$, is necessary to heat the $37 \mathrm{~m}^{3} \cdot \mathrm{s}^{-1}$ of air to elevate its temperature by 75 centigrade degrees. The specified air rate is needed to limit the NMP concentration in the dryer exit gas at 1150 ppm. The heat load would have been considerably higher without the air-to-air heat exchanger which recovers and transfers $2700 \mathrm{~kW}$ of heat from the dryer exit air to the heater inlet air. The air-to-air heat exchanger manages the heat transfer load with a surface area of $\sim 6700 \mathrm{~m}^{2}$. The other significant heat exchanger, the condenser has a higher heat transfer load of $\sim 3500 \mathrm{~kW}$, but because of the liquid water coolant the heat exchange is managed with a smaller surface area of $\sim 3300 \mathrm{~m}^{2}$. The cooling of the air, i.e., sensible heat removal, represents $93 \%$ of the condenser cooling load. The major heating and cooling loads of the components are shown in Table 2 and Figure 1.

The energy demand for this process and set of input conditions is $1470 \mathrm{~kW}$ of electricity and $4381 \mathrm{~kW}$ of thermal energy, totaling to 5,851 kW. This translates to 421 $\mathrm{kWh}$ per battery pack and $10.2 \mathrm{kWh}$ per kg of NMP. Assuming that the electric power from the grid is generated from combustion of natural gas with an efficiency of $40 \%$, the total thermal energy load from natural gas is $8056 \mathrm{~kW}(=4381+1470 / 0.4)$. The energy consumption is equivalent to 121 metric tons of $\mathrm{CO}_{2}$ per day (Equivalency Results).

\section{Table 2. Energy loads for the major components in the process (base case).}


Table 3 shows some of the contributions towards the cost of operations that were estimated with the process model. The cost of energy is split between natural gas and electricity to a total of 1.16 million dollars per year. These costs were included in a cost estimating algorithm (Peters, Timmerhaus, \& West, 2003), where percentage contributions were assumed / estimated for the different cost parameters. These are shown in column 2 of Table 4.

Table 3. Cost factors in the design and operation of the NMP drying and recovery process

Table 4. Input parameters used for cost calculations. ("Model” = Values from Table 3.)

The annual cost of operations was then calculated by adding the Total Operating Cost to the annualized Total Capital Investment. The cost of operations for the NMP drying and recovery process was estimated to be $\$ 10.6$ million per year, or $\$ 106.6$ per pack, or $\$ 2.61$ per kg of NMP evaporated in the plant. The drying and NMP recovery process contributes approximately $3 \%$ of the cost of the battery pack.

To gain perspective on the effect of inaccuracies in the assumed values in preparing the estimate, an alternative estimate was obtained by using a range of the percentages for the parameters in Table 4, which are shown in column 4. A random number generator was used to generate a percentage value within the range for each cost item to calculate the cost of dry room operations. This was repeated 1500 times, to yield an average value of \$147 per pack (10 kWh pack), with a standard deviation of $\$ 14.2$. The results were spread between a maximum and minimum of $\$ 195$ and $\$ 111$. 
The process described above is a combination of the cathode drying and the recovery of the vaporized NMP. Separating the impact of these two is important in understanding the economic rationale behind NMP recovery and recycle (instead of disposal and repurchase). One way to achieve this is by excluding the costs associated with the dryer and the air heater from the above process. The cost of the NMP recovery steps amount to $\$ 4.6$ million per year, or $\$ 45.8$ per pack, or $\$ 1.12$ per $\mathrm{kg}$ of NMP. Thus recovering NMP at a cost of $\$ 1.12$ saves $\$ 2.08$ per $\mathrm{kg}$ of NMP (purchase price $=\$ 3.20$ per $\mathrm{kg}$, Table 1), and an annual savings of approximately $\$ 8.3$ million.

\subsection{Effect of Allowable NMP in Dryer Effluent}

The equipment size and the energy demand of the system is determined by the amount of air circulating through the system, and the amount of air leaving the dryer is determined by the maximum allowable NMP concentration in the dryer air. It is expected that relaxing the allowable NMP concentration will allow a reduction in the amount of air needed, and the nature of that relationship is worth exploring. The concentration of the NMP in the dryer exit gas can be expressed as,

$$
C_{N M P}=\frac{m_{N M P}}{m_{A i r}+m_{H_{2} O}+m_{N M P}} \times 10^{6}
$$

Where, $C_{i}$ is the concentration in parts per million (ppm) and $m_{i}$ is the molar flow rate in $\mathrm{mol} \cdot \mathrm{s}^{-1}$ for the species at the dryer exit. Rearranging Equation 1 yields,

$$
m_{A i r}+m_{H_{2} O}=m_{N M P}\left(\frac{10^{6}}{C_{N M P}}-1\right) \approx\left(m_{N M P} \cdot 10^{6}\right) \cdot\left(\frac{1}{C_{N M P}}\right)
$$


The cathode material often contains a small percentage of water which is vaporized in the dryer. For simplicity these calculations assume that there is no water contribution from the cathode to the gas phase, and therefore the molar flow rate of the air and water remains constant within the dryer. Equation (2) shows that the sum of the air and water molar flow rates entering and leaving the dryer is proportional to the reciprocal of the maximum allowable NMP concentration $\left(C_{N M P}, \mathrm{ppm}\right)$, with a slope of $\left(m_{N M P} \cdot 10^{6}\right)$. The numerical results from the calculations are plotted in Figure 2, showing an almost linear relationship with $1 / C_{N M P}$. The small variation in slope is because of the interdependence of the molar flow of NMP in the dryer inlet (from the recycle gas) and at the dryer exit. The latter determines the distribution of NMP between the gas (going to the recycle stream) and liquid phases in the condenser. The molar flow rates for the variations in allowable NMP concentrations are shown in Table 5.
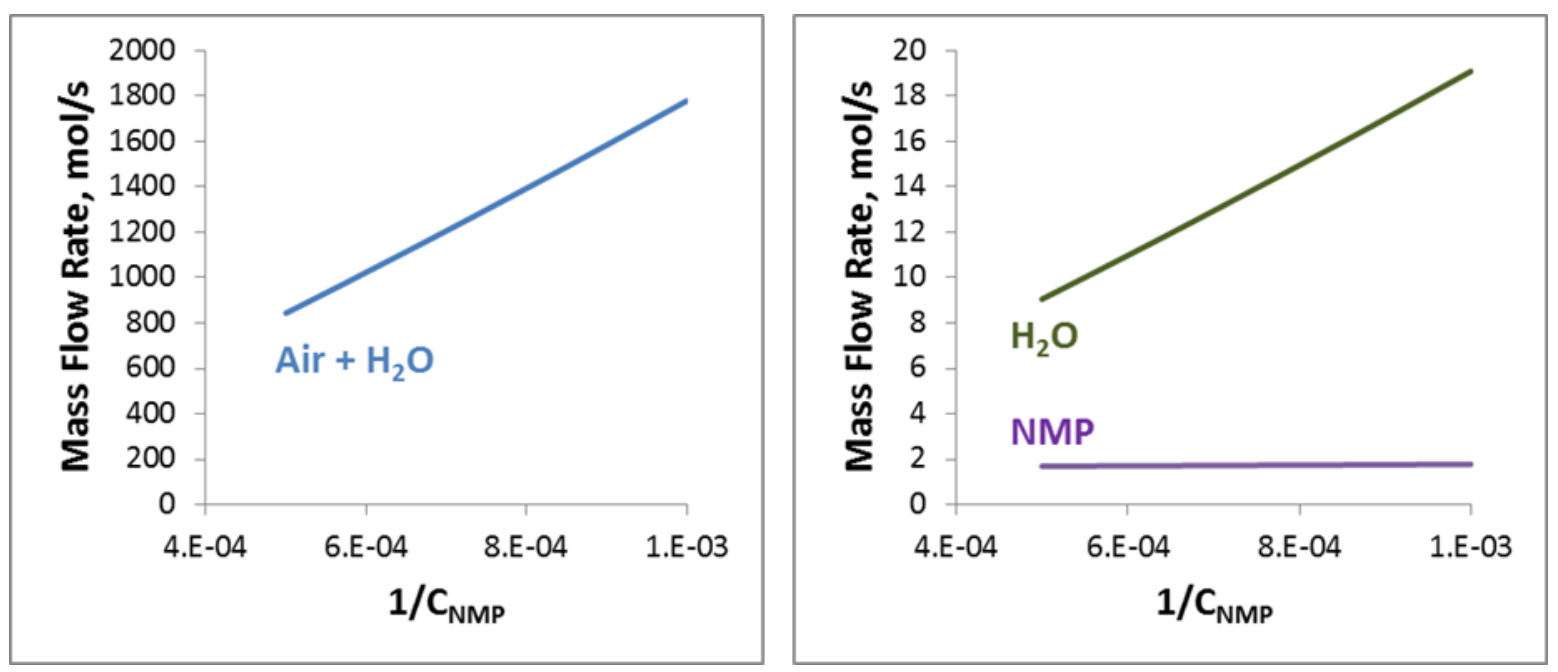

Figure 2. Effect of the allowable NMP concentration in dryer exit on the molar flow rates. 
Table 5. Effect of the allowable NMP Concentration on the Molar Flow Rate in the

\section{Dryer Exit Gas}

Doubling the maximum allowable NMP concentration from 1000 to 2000 ppm does not halve the air and water mass flow, but rather reduces it by $\sim 53 \%$. This slight compounding effect is because of the interdependence and nonlinearity discussed above.

Since the dryer gas mass flow rate is the principal driver behind the process energy needs, it follows that lower flows will show a proportional reduction in heating and cooling needs. Table 6 shows the effect of the total volumetric flow at the dryer exit on the energy needs for the process, indicating that the heat loads are linearly correlated. The total energy demand is reduced by $49.5 \%$ for a $52.5 \%$ reduction in total flow rate. It is notable that the cooling load is higher than the electricity required, because the electricity required for the cooling is reduced by the coefficient of performance (COP) factor, i.e., electric power for cooling = cooling load $/$ COP. Figure 3 shows the effect of the dryer flow rate on the cost of operations, resulting from the changed heating and cooling needs. Table 6 shows a small effect of the air flow rate on the NMP recoverability. However, the change in recovery, from $98.84 \%$ to $98.92 \%$ is equivalent to 1.8 million dollars per year in NMP purchase cost for the battery plant. The effect of allowable NMP concentration is summarized in Table 6. 


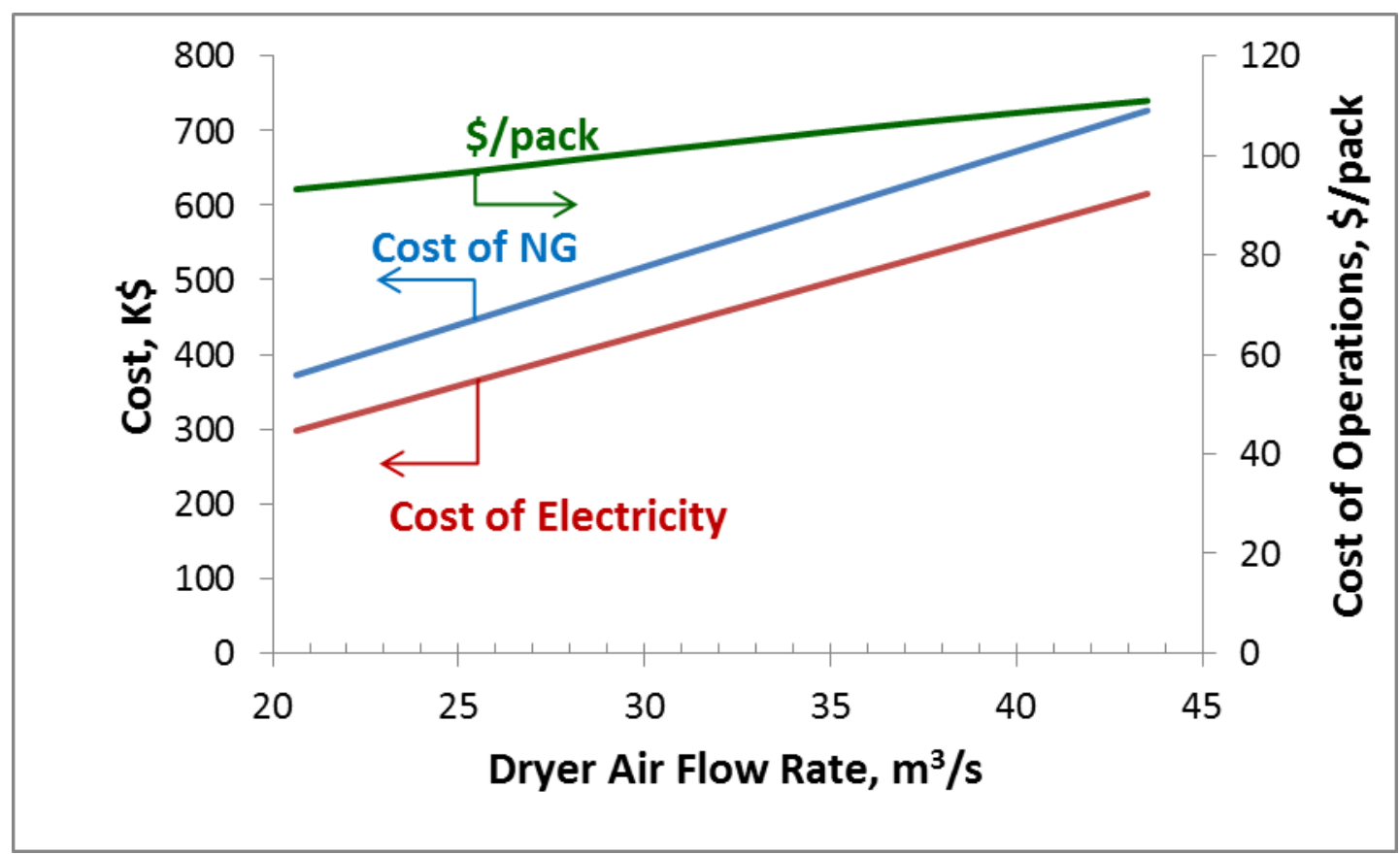

Figure 3. Effect of the dryer exit flow rate on the cost of energy and operations for the process (Electricity = 5 cents per $\mathrm{kWh}$, Natural Gas $=2$ cents per $\mathrm{kWh}, 10 \mathrm{kWh} \cdot$ pack $^{-1}$ )

Table 6. Effect of the allowable NMP concentration on energy and cost of the drying and recovery process (10 kWh·pack-1)

\subsection{Effect of Condenser Temperature}

The NMP-laden gas from the dryer is cooled to $6^{\circ} \mathrm{C}$ (for the base case) in a condenser to condense out the bulk of the NMP and water. Since NMP has a vapor pressure much lower than water, the liquid condensate carries $96 \%$ of the NMP entering the condenser, while the gas phase leaves with $87 \%$ of the water entering the condenser. Changing the condenser temperature from $4^{\circ} \mathrm{C}$ to $8^{\circ} \mathrm{C}$ changes the concentration of NMP in the gas phase from 82 to 117 ppm (Figure 4), and the concentration of water in 
the gas phase from 0.8 to $1.1 \%$. The additional NMP and water in the gas phase increases the load on the zeolite wheel. This is reflected in the heat needed to regenerate the zeolite, which increases by $18 \%$ when the temperature is raised from 4 to $8^{\circ} \mathrm{C}$. Another significant impact is seen in the size of the condenser, where the required surface area decreases from 4422 to $2848 \mathrm{~m}^{2}$, at $4^{\circ} \mathrm{C}$ and $8^{\circ} \mathrm{C}$, respectively. The chilled water used for the cooling is flowed counter-current with inlet and outlet temperatures of 3 and $13^{\circ} \mathrm{C}$, respectively. The surface area requirement decreases with higher condenser temperature setting because of the larger temperature driving force. With increasing temperature the decrease in the condenser cooling load is modest, $2 \%$ between $4-8^{\circ} \mathrm{C}$, as a result of less required cooling and condensation. Over $90 \%$ of the cooling load in the condenser is due to the sensible heat removal from the large amount of air in the system. These results are shown in Figure 4 and Table 7. Changing the condenser temperature has negligible impact on the total cost of the process.
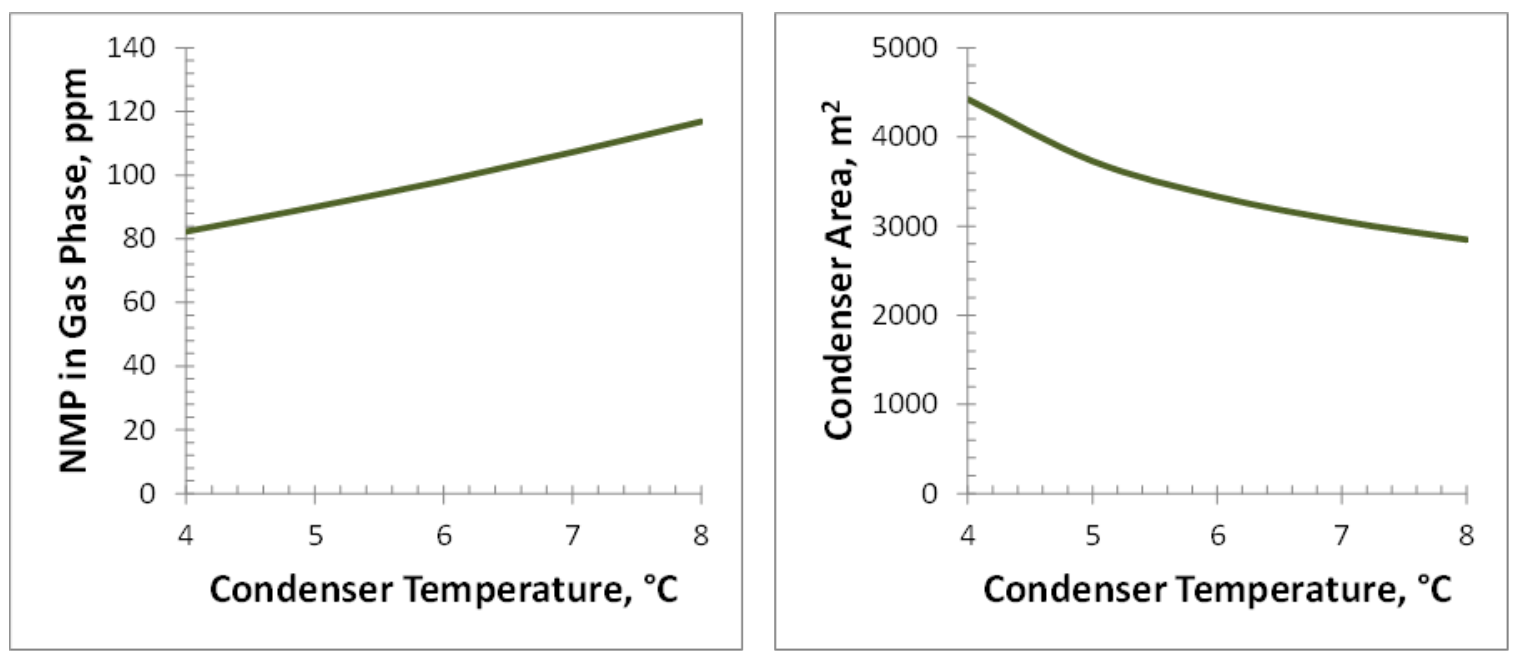

Figure 4. Effect of condenser temperature on NMP concentration in the gas phase and the condenser surface area. 


\section{Table 7. Effect of condenser temperature on the condenser effluents and its size}

\subsection{Effect of Dryer Temperature}

The dryer temperature is an important determinant in the energy and cost analysis of the process because it can affect a number of components in the system. Raising the dryer temperature, while maintaining the condenser inlet temperature, increases the size of the heat exchanger. With the larger heat exchanger, the recycled air stream recovers more sensible heat and enters the air heater at a higher temperature. Thus, the net demand on the air heater and the overall process remains essentially unchanged. The larger heat exchanger increases the cost of operations.

Raising the dryer temperature from 100 to $180^{\circ} \mathrm{C}$ increases the heat transfer load and therefore the size of the heat exchanger by almost five-fold, increases the cost of capital equipment by $22 \%$, and the cost of operations by $13 \%$. Since the condenser inlet temperature is held constant at $80^{\circ} \mathrm{C}$, and the heat exchanger size is allowed to increase, the inlet temperature to the air heater is also elevated to the same extent as the dryer temperature increase. Table 8 shows the effect of the dryer temperature on the design and operation of the process.

Higher drying temperatures are desired primarily to accelerate the drying rate, which reduces the required residence time in the dryer and thus the length of the dryer, presumably leading to lower equipment cost. However, higher temperatures do not guarantee a continuum of faster drying as the latter may become limited by the rates at 
which heat supply or mass transport takes place at some stage of drying. Various defects in the coating appear as a result of the stresses induced during the drying process. Some of the details of these complex interactions have been reported elsewhere (Westphal, Bockholt, Gunther, Haselrieder, \& Kwade, 2015) (Kim \& Hyun, 2001) (Gutoff). The extent of these effects vary with the coating composition and thickness, and need to be optimized for the specific application.

\section{Table 8. Effect of the dryer exit temperature on the process (Condenser inlet} temperature kept constant $=80^{\circ} \mathrm{C}$ )

An alternate way to evaluate the effect of the dryer exit temperature is in a scenario where the heat exchanger size is constant. In this case the condenser inlet temperature will rise resulting in a higher cooling load at the condenser. Also, the recycle air going to the air heater will recover more heat because of the larger temperature difference driving force in the heat exchanger. The heat load on the air heater will be affected as a result. The results of this scenario are shown in Figure 5. 

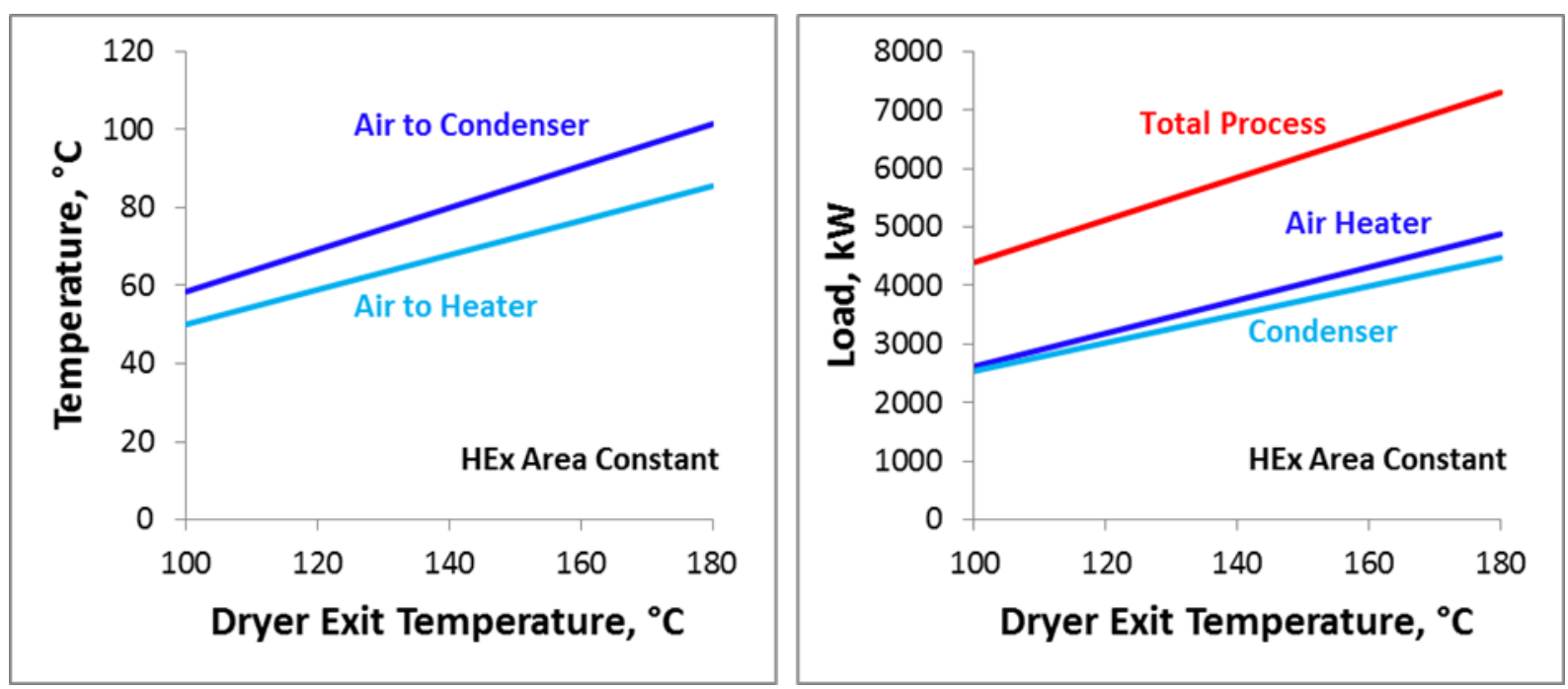

Figure 5. Effect of the dryer temperature on temperatures of the heat exchanger exit streams and the energy loads in the process (Heat exchanger area kept constant)

Increasing the dryer exit temperature by 80 centigrade degrees, from 100 to $180^{\circ} \mathrm{C}$, for a constant area heat exchanger, linearly increases the temperatures of the two exit streams from the heat exchanger. The condenser inlet temperature increases by 43 degrees, while the air heater inlet temperature increases by 36 degrees. The heat load for the air heater increases by $86 \%$; the condenser load increases by $76 \%$, and the total energy demand for the process increases by $66 \%$. The larger heat transfer load of the condenser requires a $9 \%$ larger surface area. The cost of operations increases by $9 \%$. The results are shown in Table 9.

Table 9. Effect of the dryer temperature on process parameters (Heat exchanger surface area kept constant)

Increasing the dryer temperature raises the cost of operations in both cases, with or without changing the air-air heat exchanger size. Operating the dryer at low 
temperatures has to be balanced against the costs associated with a larger footprint dryer (not reflected in these calculations).

\subsection{Sizing the Air-Air Heat Exchanger}

The heat exchanger serves to reduce the energy cost in the air heater and the condenser. There is a tradeoff between the capital cost of the heat exchanger and the two components it affects. The effect of the heat exchanger size on the cost of operations was studied by varying the temperature of the NMP-laden air leaving the heat exchanger (and entering the condenser). The results in Table 10 show that lowering the condenser inlet temperature results in a higher heat exchange load and the area requirement for the air-air heat exchanger increases sharply. The condenser, which is liquid cooled, is not affected as much. The larger air-air heat exchanger recovers more energy and reduces the load on both the air heater and the condenser, and therefore lowers the total energy need. Figure 6 shows the effect on the cost of operations, which is found to be lowest at a condenser inlet temperature of $64^{\circ} \mathrm{C}$. This operating point requires a $63 \%$ larger heat exchanger than the base case but shaves off almost $\$ 1.3$ from the cost per pack, and reduces the total energy demand for the process by $17 \%$. 


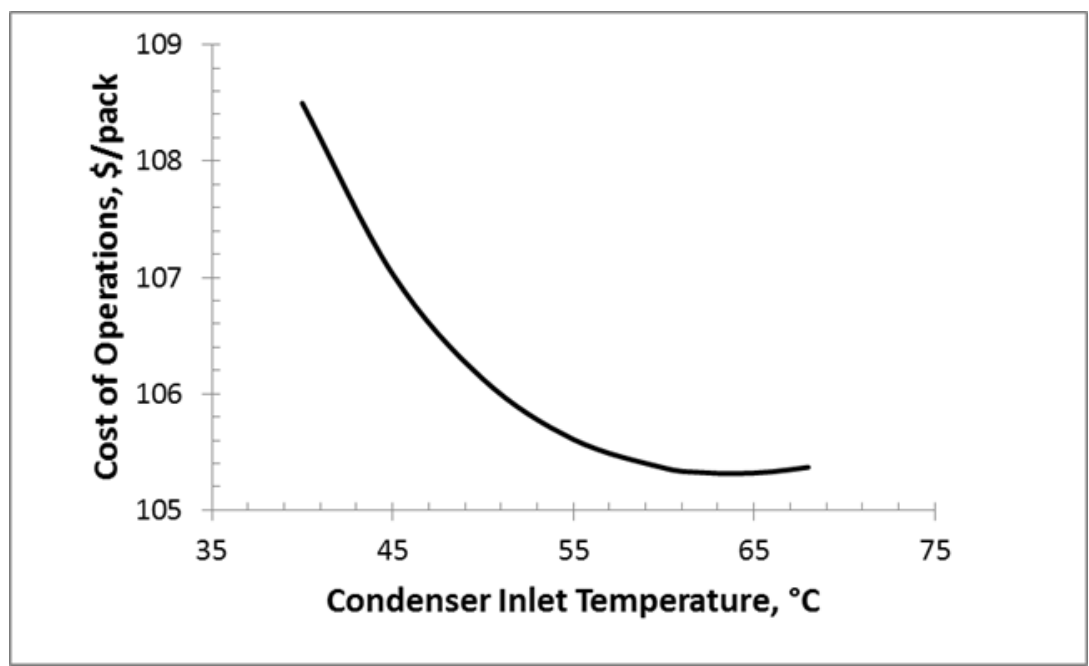

Figure 6. Effect of condenser inlet temperature on the cost of operations

Table 10. Effect of condenser inlet temperature on the heat loads, the heat exchanger sizes, and the cost of operations.

\subsection{Ambient Air Conditions}

Ambient air conditions vary widely with location and season. Cooler air requires more heating before its use in the process, while high moisture content affects the heating and cooling loads as the water is removed from the circulating air by condensation and then separated from the NMP in the distillation column via vaporization and condensation. The effect of ambient air conditions was studied by varying the temperature between $0^{\circ} \mathrm{C}$ and $40^{\circ} \mathrm{C}$, while holding the relative humidity constant at $50 \%$.

At $40^{\circ} \mathrm{C}$ the water content in the ambient air is 12 times more than that at $0^{\circ} \mathrm{C}$. The additional water shows up in the dryer inlet air and most of it leaves the system with the 
condensate from the condenser. Figure 7 shows the increase in water content in the condensate with higher ambient air temperature. The additional water in the condensate increases the heat load in the distillation column, as shown in Table 11.

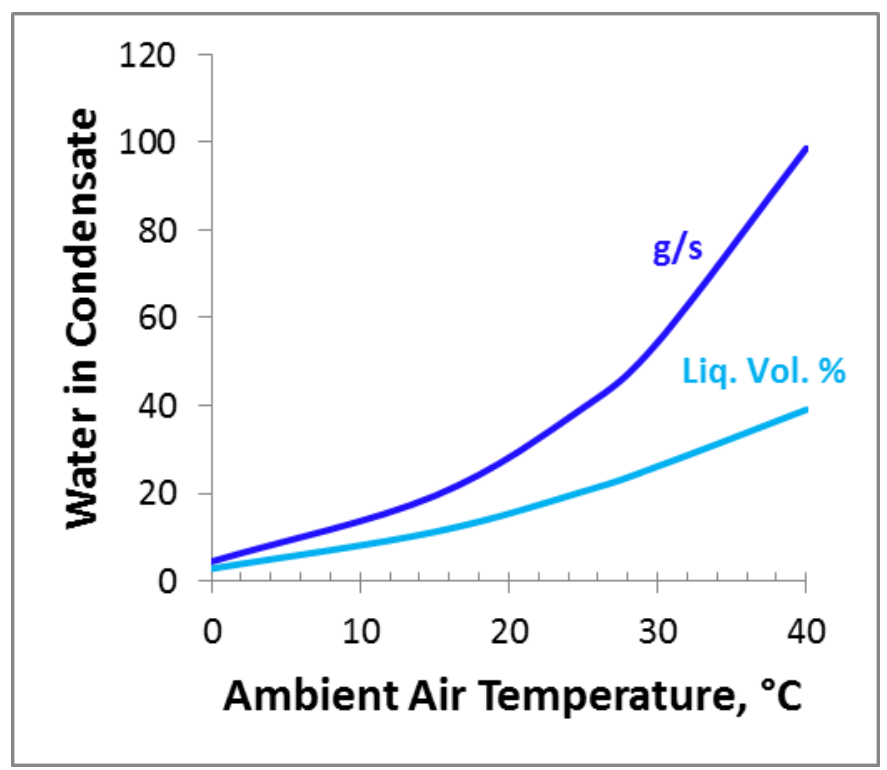

Figure 7. Effect of ambient air temperature (Relative humidity $=50 \%$ ) on the water content (gram/s or liquid volume percent) in the condensate leaving the condenser

The changing ambient air temperature changes the heating and cooling loads of the air heater and the condenser, contributing to a net higher energy need at higher ambient air temperatures. The total energy needed for the process increases by $5 \%$ when the ambient air temperature changes from 0 to $40^{\circ} \mathrm{C}$. The results are shown in Table 11 . The cost of drying and recovery operations shows a small change, with a difference of approximately $1.4 \%$ between $0^{\circ}$ and $40^{\circ} \mathrm{C}$. 
Table 11. Effect of ambient air temperature on the process parameters and cost (Ambient Air Relative humidity $=50 \%$ )

\subsection{Sensitivity to Cost Factors}

The sensitivities of several cost factors were studied. The effect of variations on factors such as the cost of capital equipment, utilities, labor, plant life, and the days of

operation per year, on the cost of operations $\left(\$ \cdot\right.$ pack $\left.^{-1}\right)$ are shown in the plot in Figure 8. Of the parameters studied, the cost of operations is most sensitive to the life of the plant; in fact, reducing the plant life to 6 years would increase the cost from $\$ 106.6$ to $\$ 142$ per pack. This effect is significant because it is likely that with rapid changes in LIB manufacturing technology, the drying and recovery process equipment may need to be changed more frequently than in other more mature technologies. A $20 \%$ change in the cost of the capital equipment leads to a little more damped effect of $8.3 \%$ (\$8.9) change in the operations cost. 


\begin{tabular}{|c|c|c|c|c|}
\hline \multicolumn{5}{|c|}{ Base Case $=\$ 106.6 /$ pack } \\
\hline Plant Life (12/Base/8) & & & \multicolumn{2}{|c|}{$+\$ 13.3$} \\
\hline Cost of Capital Equipment (-20\%/Base/+20\%) & & & $+\$ 8.9$ & \\
\hline Cost of Utilities (-20\%/Base/+20\%) & & & $+\$ 2.9$ & \\
\hline Purge Rate (5\%/Base/15\%) & & & $+\$ 2.2$ & \\
\hline Days of Operation / year (330/Base/270) & & & $+\$ 1.3$ & \\
\hline \multirow[t]{2}{*}{ Cost of Labor $(-20 \% /$ Base $/+20 \%)$} & & $-\$ 1.3$ & $+\$ 1.3$ & \\
\hline & \multicolumn{4}{|c|}{ Operations Cost, $\$ / \mathrm{kg}_{\mathrm{NMP}}$} \\
\hline
\end{tabular}

Figure 8. Sensitivity of cost of operations to various cost factors (10 kWh.pack $\left.{ }^{-1}\right)$

\section{Conclusions}

A process model has been used to study the energy and cost implications of drying the cathode and recovering the NMP solvent in a lithium ion battery plant. The results from the study reveal some interesting observations.

- The energy demand for the process is very significant at $10.2 \mathrm{kWh}$ per $\mathrm{kg}$ of NMP vaporized, and $421 \mathrm{kWh}$ per $10 \mathrm{kWh}$ battery pack. The overall energy demand is 45 times the heat needed to vaporize the NMP.

- The large energy demand is because of the large quantity of air that has to be heated and cooled. The large air flow is required by the constraint that the NMP 
concentration in the dryer has to be maintained at a far lower value than the flammability limit.

- The air heater for the coating line ovens (dryer) is the largest energy consumer in the process. There is an opportunity to lower the process energy demand and operations cost by appropriately sizing the air-air heat exchanger. Reducing the heat exchanger size, however, increases the process energy demand.

- The air entering the system can vary significantly with season and location, resulting in significant changes in the cost of operations.

- The various sensitivities indicate the process design and operating conditions can be optimized with respect to energy, cost, and perhaps both. As noted in the introduction, much cost might be saved by the use of a dry coating process.

\section{Abbreviations}

$C_{i} \quad$ Concentration of species $i$ in the gas phase, parts per million

COP Coefficient of Performance

g/s grams per second

kW kilowatt

kWh kilowatt hour

LIB Lithium ion batteries 
$m_{i} \quad$ Mass flow rate of species $i$ in the gas phase, $\mathrm{mol} / \mathrm{s}$

NMP $\quad n$-methyl pyrrolidone

ppmv Parts per million by volume

PVDF polyvinylidene difluoride

$\mathrm{RH} \quad$ Relative Humidity 


\section{Acknowledgments}

The authors wish to acknowledge Jeff Quass and David Ventola from B\&W MEGTEC, and Naresh Susarla and Gary Henriksen for their help in preparing this manuscript. Support from David Howell and Peter Faguy at the Vehicle Technologies Office, Office of Energy Efficiency and Renewable Energy, U.S. Department of Energy, is gratefully acknowledged. The submitted manuscript has been created by UChicago Argonne, LLC, Operator of Argonne National Laboratory ("Argonne"). Argonne, a U.S. Department of Energy Office of Science laboratory, is operated under contract no. DE-ACO206CH11357. The U.S. Government retains for itself, and others acting on its behalf, a paid-up nonexclusive, irrevocable worldwide license in said article to reproduce, prepare derivative works, distribute copies to the public, and perform publicly and display publicly, by or on behalf of the Government.

Abe, H., Kondo, A., Naito, M., Wakimoto, T., \& Yamaguchi, M. (2013). Electrostatic dry coating of cathode materials for Li ion battery. 9th IMAPS/ACerS International Conference and Exhibition on Ceramic Interconnect and Ceramic Microsystems Technologies, CICMT 2013. Orlando, FL.

Agency, U. S. (n.d.). Fact Sheet: N-Methylpyrrolidone (NMP). Retrieved from http://www.epa.gov/assessing-and-managing-chemicals-under-tsca/fact-sheet-nmethylpyrrolidone-nmp

Barnett, B., Ofer, D., Yang, Y., Oh, B., Rempel, J., McCoy, C., et al. (2009). PHEV Battery Cost Assessment. Annual Merit Review, EERE/DOE, . Washington DC. 
Bockholt, H., Haselrieder, W., \& Kwade, A. (2013). Intensive Dry and Wet Mixing Influencing the Structural and Electrochemical Properties of Secondary Lithium-Ion Battery Cathodes. ECS Transactions, 50 (26), 25-35.

Equivalency Results. (n.d.). (U.S. EPA) Retrieved November 24, 2015, from http://www2.epa.gov/energy/greenhouse-gas-equivalencies-calculator

Gallagher, K., \& Nelson, P. (2014). Manufacturing costs of batteries for electric vehicles. In G. Pistoria (Ed.), Lithium-Ion Batteries Advances and Applications. Amsterdam: Elsevier.

Gutoff, E. (n.d.). Fundamentals of Drying Coatings. Retrieved March 2016, from https://www.pstc.org/files/public/Gutoff.pdf

Haselrieder, W., Ivanov, S., Christen, D., Bockholt, H., \& Kwade, A. (2013). Impact of the Calendering Process on the Interfacial Structure and the Related Electrochemical Performance of Secondary Lithium-Ion Batteries. ECS Transactions, 50 (26), 59-70.

Kenney, B., Darcovich, K., MacNeil, D., \& Davidson, I. (2012). Modelling the impact of variations in electrode manufacturing on lithium-ion. Journal of Power Sources, 213, 391-401.

Kim, S., \& Hyun, J. (2001). Drying of Coated Film. In G. Wypych (Ed.), Handbook of Solvents (pp. 386-417). Toronto: ChemTec Publishing, William Andrew Publishing.

Kim, S., \& Rhee, S. (2011). A Study on Improving Drying Performance of Spinel Type LiMn2O4 as a Cathode Material for Lithium Ion Battery. International Journal Electrochemical Science, 6, 5462-5469.

Lawson, B. (n.d.). Electropaedia. Retrieved March 2016, from http://www.mpoweruk.com/battery_manufacturing.htm 
Li, J., Daniel, C., \& Wood, D. (2011). Materials processing for lithium-ion batteries. Journal of Power Sources, 196, 2452-2460.

Nelson, P., Gallagher, K., \& Bloom, I. (2012). BatPaC (Battery Performance and Cost) Software. (Argonne National Laboratory) Retrieved from http://www.cse.anl.gov/BatPaC/

Nelson, P., Gallagher, K., Bloom, I., \& Dees, D. (2011). Modeling the Performance and Cost of Lithium-Ion Batteries for Electric Vehicles. ANL Report ANL-12/55.

Park, D.-W., Canas, N., Wagner, N., \& Friedrich, K. (2016). Novel solvent-free direct coating process for battery electrodes and their electrochemical performance. Journal of Power Sources, $306,758-763$.

Peters, M., Timmerhaus, K., \& West, R. (2003). Plant Design and Economics for Chemical Engineers (Third ed.). McGraw-Hill HIgher Education.

Petri, R., Giebel, T., Zhang, B., Schunemann, J.-H., \& Hermann, C. (2015). Material cost model for innovative Li-ion battery cells in electric vehicle applications. International Journal of Precision Engineering and Manufacturing-Green Technology, 2(3), 263-268.

Smith, K., Neubauer, J., Wood, E., Jun, M., \& Pesaran, A. (2013). Models for Battery Reliability and Lifetime. Battery Congress. Ann Arbor, MI.

Tagawa, K., \& Brodd, R. (2009). Production Processes for Fabrication of Lithium-Ion Batteries. In Lithium-Ion Batteries (pp. 181-194). Springer.

Tran, H., Greco, G., Taubert, C., Wohlfahrt-Mehrens, M., Haselrieder, W., \& Kwade, A. (2012). Influence of electrode preparation on the electrochemical performance of 
LiNi0.8Co0.15Al0.05O2 composite electrodes for lithium-ion batteries. Journal of Power Sources, 210, 276-285.

Vayrynen, A., \& Salminen, J. (2012). Lithium ion battery production. Journal of Chemical Thermodynamics, 46, 80-85.

Wenzel, V., Nirschl, H., \& Notzel, D. (2015). Challenges in Lithium-lon-Battery Slurry Preparation and Potential of Modifying Electrode Structures by Different Mixing Processes. Energy Technology, 3, 692-698.

Westphal, B., Bockholt, H., Gunther, T., Haselrieder, W., \& Kwade, A. (2015). Influence of Convective Drying Parameters on Electrode Performance and Physical Electrode Properties. ECS Transactions, 64 (22), 57-68.

Wolter, M., Leiva, D., Fritsch, M., \& Borner, S. (2013). Process development and optimization for Li-ion battery production. EVS27 International Battery, Hybrid and Fuel Cell Electric Vehicle Symposium. Barcelona, Spain. 


\section{References}

1. P. Nelson, K. Gallagher, I. Bloom and D. Dees, "Modeling the Performance and Cost of Lithium-Ion Batteries for Electric Vehicles," 2011.

2. B. Lawson, "Electropaedia," [Online]. Available:

http://www.mpoweruk.com/battery_manufacturing.htm. [Accessed March 2016].

3. B. Westphal, H. Bockholt, T. Gunther, W. Haselrieder and A. Kwade, "Influence of Convective Drying Parameters on Electrode Performance and Physical Electrode Properties," ECS Transactions, vol. 64 (22), pp. 57-68, 2015.

4. S. Kim and S. Rhee, "A Study on Improving Drying Performance of Spinel Type $\mathrm{LiMn}_{2} \mathrm{O}_{4}$ as a Cathode Material for Lithium Ion Battery," International Journal Electrochemical Science, vol. 6, pp. 5462-5469, 2011.

5. P. Nelson, K. Gallagher and I. Bloom, "BatPaC (Battery Performance and Cost) Software," Argonne National Laboratory, 2012. [Online]. Available:

http://www.cse.anl.gov/BatPaC/.

6. K. Gallagher and P. Nelson, "Manufacturing costs of batteries for electric vehicles," in Lithium-Ion Batteries Advances and Applications, G. Pistoria, Ed., Amsterdam, Elsevier, 2014.

7. U. S. E. P. Agency, "Fact Sheet: N-Methylpyrrolidone (NMP)," [Online]. Available: http://www.epa.gov/assessing-and-managing-chemicals-under-tsca/fact-sheet-nmethylpyrrolidone-nmp. 
8. K. Tagawa and R. Brodd, "Production Processes for Fabrication of Lithium-Ion Batteries," in Lithium-Ion Batteries, Springer, 2009, pp. 181-194.

9. J. Li, C. Daniel and D. Wood, "Materials processing for lithium-ion batteries," Journal of Power Sources, vol. 196, pp. 2452-2460, 2011.

10. V. Wenzel, H. Nirschl and D. Notzel, "Challenges in Lithium-lon-Battery Slurry Preparation and Potential of Modifying Electrode Structures by Different Mixing Processes," Energy Technology, vol. 3, pp. 692-698, 2015.

11. H. Tran, G. Greco, C. Taubert, M. Wohlfahrt-Mehrens, W. Haselrieder and A. Kwade, "Influence of electrode preparation on the electrochemical performance of LiNi0.8Co0.15Al0.05O2 composite electrodes for lithium-ion batteries," Journal of Power Sources, vol. 210, pp. 276-285, 2012.

12. B. Kenney, K. Darcovich, D. MacNeil and I. Davidson, "Modelling the impact of variations in electrode manufacturing on lithium-ion," Journal of Power Sources, vol. 213, pp. 391-401, 2012.

13. A. Vayrynen and J. Salminen, "Lithium ion battery production," Journal of Chemical Thermodynamics, vol. 46, pp. 80-85, 2012.

14. H. Bockholt, W. Haselrieder and A. Kwade, "Intensive Dry and Wet Mixing Influencing the Structural and Electrochemical Properties of Secondary Lithium-Ion Battery Cathodes," ECS Transactions, vol. 50 (26), pp. 25-35, 2013. 
15. S. Kim and J. Hyun, "Drying of Coated Film," in Handbook of Solvents, G. Wypych, Ed., Toronto, ChemTec Publishing, William Andrew Publishing, 2001, pp. 386-417.

16. E. Gutoff, "Fundamentals of Drying Coatings," [Online]. Available: https://www.pstc.org/files/public/Gutoff.pdf. [Accessed March 2016].

17. W. Haselrieder, S. Ivanov, D. Christen, H. Bockholt and A. Kwade, "Impact of the Calendering Process on the Interfacial Structure and the Related Electrochemical Performance of Secondary Lithium-Ion Batteries," ECS Transactions, vol. 50 (26), pp. 5970, 2013.

18. M. Wolter, D. Leiva, M. Fritsch and S. Borner, "Process development and optimization for Li-ion battery production," in EVS27 International Battery, Hybrid and Fuel Cell Electric Vehicle Symposium, Barcelona, Spain, 2013.

19. H. Abe, A. Kondo, M. Naito, T. Wakimoto and M. Yamaguchi, "Electrostatic dry coating of cathode materials for Li ion battery," in 9th IMAPS/ACerS International Conference and Exhibition on Ceramic Interconnect and Ceramic Microsystems Technologies, CICMT 2013, Orlando, FL, 2013.

20. R. Petri, T. Giebel, B. Zhang, J.-H. Schunemann and C. Hermann, "Material cost model for innovative Li-ion battery cells in electric vehicle applications," International Journal of Precision Engineering and Manufacturing-Green Technology, vol. 2, no. 3, pp. 263-268, 2015. 
21. B. Barnett, D. Ofer, Y. Yang, B. Oh, J. Rempel, C. McCoy, T. Rhodes, M. Hastbaca and S. Sriramulu, "PHEV Battery Cost Assessment," in Annual Merit Review, EERE/DOE, , Washington DC, 2009.

22. K. Smith, J. Neubauer, E. Wood, M. Jun and A. Pesaran, "Models for Battery Reliability and Lifetime," in Battery Congress, Ann Arbor, MI, 2013.

23. U.S. EPA, "Equivalency Results," [Online]. Available: http://www2.epa.gov/energy/greenhouse-gas-equivalencies-calculator. [Accessed 24 November 2015].

24. M. Peters, K. Timmerhaus and R. West, Plant Design and Economics for Chemical Engineers, Third ed., McGraw-Hill HIgher Education, 2003.

25. D.-W. Park, N. Canas, N. Wagner and K. Friedrich, "Novel solvent-free direct coating process for battery electrodes and their electrochemical performance," Journal of Power Sources, vol. 306, pp. 758-763, 2016. 
Table 1. Input parameters for the Base Case set of design and operating conditions

\begin{tabular}{|c|c|}
\hline NMP evaporated, kg per year & $4.134 \mathrm{M}$ \\
\hline No. of days of operation, days per year & 300 \\
\hline Plant life (Depreciation Period), years & 10 \\
\hline Purge / Make-Up Air, \% of air entering dryer & 10 \\
\hline Temperature of Make-Up Air, ${ }^{\circ} \mathrm{C}$ & 25 \\
\hline Relative Humidity (RH) of Make-Up Air, \% & 50 \\
\hline Allowable concentration of NMP in Dryer Air, ppm & 1150 \\
\hline Dryer air exit temperature, ${ }^{\circ} \mathrm{C}$ & 140 \\
\hline Condenser inlet temperature, ${ }^{\circ} \mathrm{C}$ & 80 \\
\hline Condenser exit temperature, ${ }^{\circ} \mathrm{C}$ & 6 \\
\hline Coefficient of Performance & 3 \\
\hline Recycle Stream, \% of Condenser exit air & 90 \\
\hline NMP recovery at zeolite wheel, $\%$ & 85 \\
\hline NMP recovery at distillation column, \% & 99 \\
\hline Maximum temperature in distillation column, ${ }^{\circ} \mathrm{C}$ & 250 \\
\hline Zeolite capacity, g-NMP per g-zeolite & 0.001 \\
\hline Zeolite wheel cycle time, hour & 2 \\
\hline Zeolite wheel replaced each year, \% & 50 \\
\hline Price of NMP, $\$ \cdot \mathrm{kg}^{-1}$ & 3.20 \\
\hline Price of natural gas, $\$ \cdot \mathrm{kWh}^{-1}$ & 0.02 \\
\hline Price of electricity, $\$ \cdot \mathrm{kWh}^{-1}$ & 0.05 \\
\hline
\end{tabular}


Table 2. Energy loads for the major components in the process (base case).

\begin{tabular}{|l|r|}
\hline Component & Load \\
\hline Cathode Dryer, kW & 130 \\
\hline Air Heater, kW & 3752 \\
\hline Air-to-Air Heat Exchanger heat exchange load, kW & 2700 \\
\hline Air-to-Air Heat Exchanger surface area, ${ }^{2}$ & 6714 \\
\hline Condenser cooling load, kW & 3508 \\
\hline Condenser surface area, ${ }^{2}$ & 3332 \\
\hline Distillation Column Heat Load, kW & 394 \\
\hline Zeolite Regeneration Heater, kW & 236 \\
\hline Electric Power for Chiller, kW & 1169 \\
\hline Electric Power for Air Blowers, kW & 301 \\
\hline Total Electricity Demand, kW & 1470 \\
\hline Total Thermal Energy Demand (from Natural Gas), kW & 4381 \\
\hline Total Energy Demand for NMP Drying and Recovery, kW & 5851 \\
\hline
\end{tabular}


Table 3. Cost factors in the design and operation of the NMP drying and recovery process

\begin{tabular}{|l|r|r|}
\hline Cost Parameters from Model & $10^{6} \mathbf{\$}$ & $\begin{array}{r}\% \text { of Annual } \\
\text { Cost }\end{array}$ \\
\hline Total Capital Investment & 26.4 & $24.8 \%$ \\
\hline Cost of Electricity $\left(@ 0.05 \$ \cdot \mathrm{kWh}^{-1}\right)$ & 0.53 per year & $5.0 \%$ \\
\hline Cost of Natural Gas (@ 0.02 \$.kWh $\left.{ }^{-1}\right)$ & 0.63 per year & $5.9 \%$ \\
\hline Cost of Labor & 0.52 per year & $4.9 \%$ \\
\hline Cost of Utilities & 1.30 per year & $12.2 \%$ \\
\hline
\end{tabular}


Table 4. Input parameters used for cost calculations. ("Model” = Values from Table 3.)

\begin{tabular}{|c|c|c|c|}
\hline Assumption / Input Parameter & Estimated \% & Of & Range \% \\
\hline \multicolumn{4}{|l|}{ 1. Direct Costs } \\
\hline A. Purchased Equipment & Model & & Model \\
\hline Installation & $35 \%$ & Purchased Equipment & $20-35 \%$ \\
\hline B. Buildings, process and auxiliary & Model & Purchased Equipment & Model \\
\hline C. Service facilities and yard improvements & $0 \%$ & Purchased Equipment & $0 \%$ \\
\hline D. Land & $0 \% *$ & Purchased Equipment & $0 \% *$ \\
\hline \multicolumn{4}{|l|}{ 2. Indirect Costs } \\
\hline A. Engineering and supervision & $5 \%$ & Direct Costs & $5-10 \%$ \\
\hline B. Construction expense and contractor's fee & $10 \%$ & Direct Costs & $5-15 \%$ \\
\hline C. Contingency & $5 \%$ & Fixed Cap. Investment & $5-10 \%$ \\
\hline \multicolumn{4}{|l|}{ 3. Fixed Capital Investment $=1+2$} \\
\hline 4. Working Capital & $5 \%$ & Fixed Cap. Investment & $5-10 \%$ \\
\hline \multicolumn{4}{|l|}{ 5. Total Capital Investment $=3+4$} \\
\hline \multicolumn{4}{|l|}{ I. Operating Cost, \$/year } \\
\hline \multicolumn{4}{|l|}{ A. Direct Product Costs } \\
\hline Raw Materials & Model & & Model \\
\hline Operating labor & Model & & Model \\
\hline Direct supervisory and clerical labor & $15 \%$ & Operating Labor & $10-20 \%$ \\
\hline Utilities & Model & & Model \\
\hline Maintenance and Repairs & $5 \%$ & Fixed Cap. Investment & $2-8 \%$ \\
\hline Operating supplies & $0.5 \%$ & Fixed Cap. Investment & $0.5-1 \%$ \\
\hline Laboratory charges & $10 \%$ & Operating Labor & $0 \%$ \\
\hline Patents and royalties & $0 \%$ & Total Operating Cost & $0 \%$ \\
\hline \multicolumn{4}{|l|}{ B. Fixed Charges } \\
\hline Depreciation & Model & & Model \\
\hline Local taxes & $3 \%$ & Fixed Cap. Investment & $1-4 \%$ \\
\hline Insurance & $1 \%$ & Fixed Cap. Investment & $0.6-1 \%$ \\
\hline Rent & $0 \%$ & Fixed Cap. Investment & 0 \\
\hline C. Plant Overhead Costs & $10 \%$ & Total Operating Cost & $5-15 \%$ \\
\hline \multicolumn{4}{|l|}{ II. General Expenses } \\
\hline A. Administrative costs & $2 \%$ & Total Operating Cost & $2-6 \%$ \\
\hline B. Distribution and selling costs & $0 \%$ & Total Operating Cost & $0 \%$ \\
\hline C. $R \& D$ costs & $1 \%$ & Total Operating Cost & $1-3 \%$ \\
\hline D. Financing & $6 \%$ & Fixed Cap. Investment & $3-8 \%$ \\
\hline \multicolumn{4}{|l|}{ III. Total Operating Cost, $\$ /$ year $=I+I I$} \\
\hline *included in 1B (Buildings, process and auxiliary) & & & \\
\hline
\end{tabular}


Table 5. Effect of the allowable NMP Concentration on the Molar Flow Rate in the Dryer Exit Gas

\begin{tabular}{|c|r|r|r|r|r|}
\hline Allowable NMP Concentration, $\boldsymbol{C}_{\boldsymbol{N M P}}, \mathbf{p p m}$ & $\mathbf{1 0 0 0}$ & $\mathbf{1 1 5 0}$ & $\mathbf{1 4 0 0}$ & $\mathbf{1 7 0 0}$ & $\mathbf{2 0 0 0}$ \\
\hline Air, $\boldsymbol{m}_{\text {Air }}, \mathrm{mol} / \mathrm{s}$ & 1761 & 1510 & 1220 & 991 & 835 \\
\hline Water, $\boldsymbol{m}_{\boldsymbol{H}_{\mathbf{2}} \boldsymbol{O}, \mathrm{mol} / \mathrm{s}}$ & 19.1 & 16.4 & 13.2 & 10.8 & 9.1 \\
\hline $\mathrm{NMP}, \boldsymbol{m}_{\boldsymbol{N} M P}, \mathrm{~mol} / \mathrm{s}$ & 1.78 & 1.76 & 1.73 & 1.71 & 1.69 \\
\hline Total Dryer Exit Flow, mol/s & 1782 & 1528 & 1235 & 1004 & 846 \\
\hline
\end{tabular}


Table 6. Effect of the allowable NMP concentration on energy and cost of the drying and recovery process (10 kWh. pack $^{-1}$ )

\begin{tabular}{|c|c|c|c|c|c|}
\hline Allowable NMP Concentration, $C_{N M P}, \mathrm{ppm}$ & 1000 & 1150 & 1400 & 1700 & 2000 \\
\hline Flow Rate at Dryer Exit, $\mathrm{m}^{3} \mathrm{~s}^{-1}$ & 43.6 & 37.4 & 30.2 & 24.5 & 20.7 \\
\hline Cooling Load, kW & 4075 & 3508 & 2853 & 2337 & 1983 \\
\hline Thermal Energy Demand, kW & 5049 & 4381 & 3610 & 3002 & 2585 \\
\hline Electricity Demand, kW & 1709 & 1470 & 1194 & 976 & 827 \\
\hline Total Energy Demand, kW & 6758 & 5851 & 4804 & 3978 & 3412 \\
\hline Cost of Electricity $\left(5 \mathrm{c} \mathrm{kWh}{ }^{-1}\right)$ & 615 & 529 & 430 & 351 & 298 \\
\hline Cost of Natural Gas (2 c kWh $\left.{ }^{-1}\right)$ & 727 & 631 & 520 & 432 & 372 \\
\hline NMP Recovery, \% & 98.84 & 98.86 & 98.89 & 98.91 & 98.92 \\
\hline Cost of Operations (Drying and Recovery), $\$ \cdot$ pack $^{-1}$ & 111 & 107 & 101 & 96 & 93 \\
\hline Cost of Operations (Drying and Recovery), $\$ \cdot \mathrm{kWh}^{-1}$ & 11.1 & 10.7 & 10.1 & 9.6 & 9.3 \\
\hline
\end{tabular}


Table 7. Effect of condenser temperature on the condenser effluents and its size

\begin{tabular}{|l|r|r|r|r|r|}
\hline Condenser Temperature, $^{\circ} \mathbf{C}$ & $\mathbf{4}$ & $\mathbf{5}$ & $\mathbf{6}$ & $\mathbf{7}$ & $\mathbf{8}$ \\
\hline NMP Concentration in Vapor Phase, ppm & 82 & 90 & 98 & 107 & 117 \\
\hline NMP Concentration in Liquid Phase, mol. \% & 42.29 & 42.28 & 42.26 & 42.24 & 42.22 \\
\hline $\mathrm{H}_{2} \mathrm{O}$ Concentration in Vapor Phase, mol. \% & 0.81 & 0.87 & 0.93 & 1.00 & 1.07 \\
\hline $\mathrm{H}_{2} \mathrm{O}_{\text {Concentration in Liquid Phase, mol. \% }}$ & 57.71 & 57.72 & 57.74 & 57.76 & 57.78 \\
\hline Condenser Cooling Load, kW & 3547 & 3527 & 3508 & 3491 & 3476 \\
\hline Condenser Surface Area, m ${ }^{2}$ & 4422 & 3728 & 3332 & 3056 & 2848 \\
\hline Heat Load for Zeolite Regeneration, kW & 217 & 226 & 236 & 246 & 257 \\
\hline
\end{tabular}


Table 8. Effect of the dryer exit temperature on the process (Condenser inlet temperature kept constant $=80^{\circ} \mathrm{C}$ )

\begin{tabular}{|c|c|c|c|c|c|}
\hline Dryer Exit Temperature, ${ }^{\circ} \mathrm{C}$ & 100 & 120 & 140 & 160 & 180 \\
\hline Heat Exchanger Surface Area, $\mathrm{m}^{2}$ & 2265 & 4503 & 6714 & 8899 & 11059 \\
\hline Total Energy Demand, kW & 5743 & 5797 & 5851 & 5905 & 5959 \\
\hline Cost of Capital Equipment, $\mathrm{M} \$$ & 3.41 & 3.61 & 3.80 & 3.99 & 4.17 \\
\hline Cost of Operations (Drying and Recovery), $\$ \cdot$ pack $^{-1}$ & 104 & 105 & 107 & 108 & 109 \\
\hline
\end{tabular}


Table 9. Effect of the dryer temperature on process parameters (Heat exchanger surface area kept constant)

\begin{tabular}{|c|c|c|c|c|c|}
\hline Dryer Exit Temperature, ${ }^{\circ} \mathrm{C}$ & 100 & 120 & 140 & 160 & 180 \\
\hline Temperature of Air to Condenser Inlet, ${ }^{\circ} \mathrm{C}$ & 59 & 69 & 80 & 91 & 101 \\
\hline Temperature of Air to Air Heater, ${ }^{\circ} \mathrm{C}$ & 50 & 59 & 68 & 77 & 86 \\
\hline Air Heater Load, kW & 2621 & 3186 & 3752 & 4317 & 4882 \\
\hline Condenser Cooling Load, kW & 2541 & 3025 & 3508 & 3992 & 4476 \\
\hline Total Energy Demand, kW & 4398 & 5125 & 5851 & 6578 & 7304 \\
\hline Cost of Operations, $\$ \cdot$ pack $^{-1}$ & 101.8 & 104.6 & 106.6 & 108.7 & 110.8 \\
\hline
\end{tabular}


Table 10. Effect of condenser inlet temperature on the heat loads, the heat exchanger sizes, and the cost of operations.

\begin{tabular}{|c|c|c|c|c|c|c|}
\hline Condenser Inlet Temperature, ${ }^{\circ} \mathrm{C}$ & 40 & 50 & 60 & 64 & 68 & 80 \\
\hline Air-Air Heat Exchanger Load, kW & 4500 & 4050 & 3600 & 3420 & 3240 & 2700 \\
\hline Air Heater Load, kW & 1847 & 2323 & 2799 & 2990 & 3180 & 3752 \\
\hline Condenser Load, kW & 1708 & 2158 & 2608 & 2788 & 2968 & 3508 \\
\hline Heat Exchanger Surface Area, $\mathrm{m}^{2}$ & 25035 & 17205 & 12371 & 10918 & 9658 & 6714 \\
\hline Condenser Surface Area, $\mathrm{m}^{2}$ & 3060 & 3120 & 3192 & 3220 & 3249 & 3332 \\
\hline Total Energy Demand, kW & 3346 & 3972 & 4599 & 4849 & 5100 & 5851 \\
\hline Cost of Operations, $\$ \cdot$ pack $^{-1}$ & 108.5 & 106.1 & 105.4 & 105.3 & 105.4 & 106.6 \\
\hline
\end{tabular}


Table 11. Effect of ambient air temperature on the process parameters and cost

(Ambient Air Relative humidity $=50 \%$ )

\begin{tabular}{|l|r|r|r|r|r|}
\hline Ambient Air Temperature, ${ }^{\circ} \mathbf{C}$ & $\mathbf{0}$ & $\mathbf{1 5}$ & $\mathbf{2 5}$ & $\mathbf{3 0}$ & $\mathbf{4 0}$ \\
\hline $\mathrm{H}_{2} \mathrm{O}$ in Make-Up Air, mol/s & 0.46 & 1.29 & 2.41 & 3.24 & 5.69 \\
\hline $\mathrm{H}_{2} \mathrm{O}$ in Condensate, mol/s & 0.25 & 1.08 & 2.20 & 3.03 & 5.48 \\
\hline $\mathrm{H}_{2} \mathrm{O}$ in Condensate, liquid vol. \% & 2.8 & 11.2 & 20.4 & 26.1 & 39.1 \\
\hline Air Heater Load, kW & 3755 & 3753 & 3752 & 3750 & 3746 \\
\hline Condenser Cooling Load, kW & 3422 & 3459 & 3508 & 3545 & 3653 \\
\hline Distillation Column Load, kW & 237 & 304 & 394 & 461 & 659 \\
\hline Total Energy Demand, kW & 5778 & 5790 & 5851 & 5907 & 6092 \\
\hline Cost of Operations, \$.pack ${ }^{-1}$ & 105.7 & 106.5 & 106.6 & 106.8 & 107.3 \\
\hline
\end{tabular}

